\title{
Aquabacterium limnoticum sp. nov., isolated from a freshwater spring
}

\author{
Correspondence \\ Shih-Yi Sheu \\ sys816@mail.nkmu.edu.tw
}

\author{
Wen-Ming Chen, ${ }^{1}$ Nian-Tsz Cho, ${ }^{1}$ Shwu-Harn Yang, ${ }^{2}$ A. B. Arun, ${ }^{3}$ \\ Chiu-Chung Young ${ }^{4}$ and Shih-Yi Sheu ${ }^{2}$
${ }^{1}$ Laboratory of Microbiology, Department of Seafood Science, National Kaohsiung Marine University, no. 142, Hai-Chuan Rd, Nan-Tzu, Kaohsiung City 811, Taiwan, ROC
${ }^{2}$ Department of Marine Biotechnology, National Kaohsiung Marine University, no. 142, Hai-Chuan Rd, Nan-Tzu, Kaohsiung City 811, Taiwan, ROC
${ }^{3}$ Yenepoya Research Center, Yenepoya University, University Rd, Deralakatee, Mangalore, Karnataka State, India National Chung Hsing University, Taichung 402, Taiwan, ROC \\ ${ }^{4}$ College of Agriculture and Natural Resources, Department of Soil and Environmental Sciences,
}

\begin{abstract}
A Gram-negative, facultatively anaerobic, short-rod-shaped, non-motile and non-spore-forming bacterial strain, designated $\mathrm{ABP}-4^{\top}$, was isolated from a freshwater spring in Taiwan and was characterized using the polyphasic taxonomy approach. Growth occurred at $20-40{ }^{\circ} \mathrm{C}$ (optimum, $30-37{ }^{\circ} \mathrm{C}$ ), at $\mathrm{pH} 7.0-10.0$ (optimum, $\mathrm{pH} 7.0-9.0$ ) and with $0-3 \% \mathrm{NaCl}$ (optimum, $0 \%$ ).

Phylogenetic analyses based on 16S rRNA gene sequences showed that strain ABP- $4^{\top}$, together with Aquabacterium fontiphilum CS- $6^{\top}$ (96.4\% sequence similarity), Aquabacterium commune $\mathrm{B}^{\top}$ (96.1\%), Aquabacterium citratiphilum B4 ${ }^{\top}$ (95.5\%) and Aquabacterium parvum B6 ${ }^{\top}$ $(94.7 \%)$, formed a deep line within the order Burkholderiales. Strain ABP- $4^{\top}$ contained summed feature 3 (comprising $C_{16: 1} \omega 7 c$ and/or $C_{16: 1} \omega 6 c$ ), $C_{18: 1} \omega 7 c$ and $C_{16: 0}$ as predominant fatty acids. The major cellular hydroxy fatty acid was $\mathrm{C}_{10: 0} 3-\mathrm{OH}$. The major isoprenoid quinone was Q-8 and the DNA G + C content was 68.6 mol\%. The polar lipid profile consisted of a mixture of phosphatidylethanolamine, phosphatidylglycerol, phosphatidylserine, diphosphatidylglycerol and several uncharacterized phospholipids. The DNA-DNA relatedness of strain ABP- $4^{\top}$ with respect to recognized species of the genus Aquabacterium was less than $70 \%$. On the basis of the genotypic, chemotaxonomic and phenotypic data, strain $\mathrm{ABP}-4^{\top}$ represents a novel species in the genus Aquabacterium, for which the name Aquabacterium limnoticum sp. nov. is proposed. The type strain is $\mathrm{ABP}-4^{\top}\left(=\mathrm{BCRC} 80167^{\top}=\right.$ KCTC $\left.23306^{\top}\right)$.
\end{abstract}

The genus Aquabacterium, belonging to the SphaerotilusLeptothrix group within the order Burkholderiales of the class Betaproteobacteria, was proposed by Kalmbach et al. (1999). At the time of writing, this genus comprises four recognized species: Aquabacterium citratiphilum, Aquabacterium parvum and Aquabacterium commune, isolated from the Berlin drinking water system (Kalmbach et al., 1999), and Aquabacterium fontiphilum, isolated from Taiwan spring water (Lin et al., 2009). Members of the genus Aquabacterium are characterized as Gram-negative, facultatively anaerobic, rod-shaped, motile by means of monotrichous flagella,

The GenBank/EMBL/DDBJ accession number for the $16 \mathrm{~S}$ rRNA gene sequence of Aquabacterium limnoticum strain ABP-4 ${ }^{\top}$ is GU319965.

A supplementary figure, showing 2D TLC of polar lipids of strain ABP- $4^{\top}$, and a supplementary table, showing GN2 microplate oxidation data, are available with the online version of this paper. oxidase-positive and catalase-negative, and chemotaxonomically highly diverse having summed feature 3, C18: $1 \omega 7 c$ and C16:0 as predominant fatty acids and by having a DNA $\mathrm{G}+\mathrm{C}$ content between 63.4 and $66.0 \mathrm{~mol} \%$ (Kalmbach et al., 1999; Lin et al., 2009). The present study was carried out to clarify the taxonomic position of the Aquabacterium-like bacterial strain $\mathrm{ABP}-4^{\mathrm{T}}$ by using a polyphasic taxonomy approach.

During the characterization of micro-organisms from a freshwater spring (GPS location: $24^{\circ} 7^{\prime} 15.1^{\prime \prime} \mathrm{N} 120^{\circ} 40^{\prime}$ $27.4^{\prime \prime} \mathrm{E}$; pH 7.8, $28^{\circ} \mathrm{C}$ ) in Taichung County, Taiwan, a semitransparent colony was isolated and selected for detailed analysis; this bacterial strain was designated ABP- $4^{\mathrm{T}}$. Strain ABP $-4^{\mathrm{T}}$ was isolated on R2A agar (BD Difco) plates after incubating at $25{ }^{\circ} \mathrm{C}$ for 3 days. Subcultivation was performed on R2A agar at $25{ }^{\circ} \mathrm{C}$ for $48-72 \mathrm{~h}$. On this medium, strain $\mathrm{ABP}-4^{\mathrm{T}}$ was able to grow at $25-40{ }^{\circ} \mathrm{C}$. It was preserved at 
$-80{ }^{\circ} \mathrm{C}$ in R2A broth with $20 \%$ (v/v) glycerol or by lyophilization. A. citratiphilum $\mathrm{B} 4^{\mathrm{T}}$, A. parvum $\mathrm{B} 6^{\mathrm{T}}$ and $A$. commune $B 8^{\mathrm{T}}$ were obtained from the Deutsche Sammlung von Mikroorganismen und Zellkulturen (DSMZ), and A. fontiphilum CS- $6^{\mathrm{T}}$ was obtained from the Bioresource Collection and Research Center (BCRC). All four type strains were used as reference strains for phenotypic and genotypic tests.

The bacterial cells were observed by phase-contrast microscopy (DM 2000; Leica) using cells grown on R2A agar at $30{ }^{\circ} \mathrm{C}$ for $6 \mathrm{~h}$ (lag phase), $18 \mathrm{~h}$ (exponential phase) and $36 \mathrm{~h}$ (stationary phase) to ascertain the morphology. Cellular motility was tested by using the hanging drop method. The Gram Stain Set S (BD Difco) kit and the Ryu non-staining $\mathrm{KOH}$ method (Powers, 1995) were used for testing the Gram reaction. Poly- $\beta$-hydroxybutyrate granule accumulation was observed under light microscopy after staining of the cells with Sudan black. Colony morphology was observed on R2A agar using a stereoscopic microscope (SMZ 800; Nikon).

The $\mathrm{pH}$ range for growth was determined by measuring the $\mathrm{OD}_{600}$ of $\mathrm{R} 2 \mathrm{~A}$ broth cultures. The $\mathrm{pH}$ was adjusted to $\mathrm{pH} 4$ 11 (at intervals of $1.0 \mathrm{pH}$ unit) prior to sterilization using appropriate biological buffers (Breznak \& Costilow, 1994): citrate/ $\mathrm{Na}_{2} \mathrm{HPO}_{4}$ buffer, $\mathrm{pH}$ range 4.0-5.0; phosphate buffer, $\mathrm{pH}$ range 6.0-7.0; Tris buffer, $\mathrm{pH}$ range 8.0-9.0; no buffer, $\mathrm{pH}$ range 10.0-11.0. Verification of the $\mathrm{pH}$ values after autoclaving revealed only minor changes. The temperature range for growth was determined on R2A broth by culturing at $4-50{ }^{\circ} \mathrm{C}$. To investigate the tolerance to $\mathrm{NaCl}, \mathrm{R} 2 \mathrm{~A}$ broth was prepared according to the formula of the $\mathrm{BD}$ Difco medium with $\mathrm{NaCl}$ concentration adjusted to $0,0.5$ and 1.0 $10.0 \%, \mathrm{w} / \mathrm{v}$ (at intervals of $1.0 \%$ ). Growth under anaerobic conditions was determined after incubating strain ABP- $4^{\mathrm{T}}$ on R2A agar in the Oxoid AnaeroGen system. The potential utilization of various electron acceptors $\left[\mathrm{KNO}_{3}, \mathrm{KNO}_{2}\right.$, $\mathrm{NaClO}_{3}, \mathrm{Na}_{2} \mathrm{SO}_{4}$ or iron (III) citrate] was studied as described by Kalmbach et al. (1999). Strain ABP-4 ${ }^{\mathrm{T}}$ was examined for a broad range of phenotypic properties. Activities of catalase, oxidase, urease and lipase (corn oil), and hydrolysis of starch, casein, gelatin and Tweens 20, 40, 60 and 80 were determined using standard methods (Smibert \& Krieg, 1994). Catalase production was demonstrated on a slide by the production of bubbles from a drop of a $3 \%$ hydrogen peroxide solution. Heavy inoculation of standard Christensen urea agar medium was used to demonstrate urease production. The gelatin liquefaction test was performed by using R2A broth supplemented with $4 \%$ gelatin and incubated at the optimum growth temperature. Additional biochemical tests were performed using API ZYM, and API 20NE kits (bioMérieux) and carbon source utilization was evaluated using the GN2 microplate (Biolog). All commercial phenotypic tests were performed according to the manufacturers' recommendations.

The sensitivity of strain ABP- $4^{\mathrm{T}}$ to antibiotics was tested by using the disc diffusion method after spreading cell suspensions (0.5 McFarland) on R2A agar (BD Difco) plates.
The discs (Oxoid) contained the following antibiotics: ampicillin $(10 \mu \mathrm{g})$, chloramphenicol $(30 \mu \mathrm{g})$, gentamicin $(10 \mu \mathrm{g})$, kanamycin $(30 \mu \mathrm{g})$, nalidixic acid $(30 \mu \mathrm{g})$, novobiocin $(30 \mu \mathrm{g})$, rifampicin $(5 \mu \mathrm{g})$, penicillin $\mathrm{G}(10 \mu \mathrm{g})$, streptomycin $(10 \mu \mathrm{g})$, sulfamethoxazole $(23.75 \mu \mathrm{g})$ plus trimethoprim $(1.25 \mu \mathrm{g})$ and tetracycline $(30 \mu \mathrm{g})$. The effect of antibiotics on cell growth was assessed after 2 days growth at $30{ }^{\circ} \mathrm{C}$. The diameter of the antibiotic disc is $8 \mathrm{~mm}$. The strain was considered susceptible when the diameter of the inhibition zone was $>13 \mathrm{~mm}$, intermediate at $10-12 \mathrm{~mm}$ and resistant at $<10 \mathrm{~mm}$, as described by Nokhal \& Schlegel (1983).

Genomic DNA was isolated by using a bacterial genomic kit and the 16S rRNA gene sequence was analysed as described by Chen et al. (2001). Primers FD1 (5'-AGAGTTTGATCCTGGCTCAG-3') and RD1 (5'-AAGGAGGTGATCCAGCC- $3^{\prime}$ ) were used for amplification of bacterial $16 \mathrm{~S}$ rRNA genes by PCR. These primers correspond to nucleotide positions 8-27 and 1525-1541 of the Escherichia coli 16S rRNA gene, respectively, and can be used to amplify a nearly full-length 16S rRNA gene. The PCR product was purified, and direct sequencing was performed by using sequencing primers FD1/RD1 and 520F/800R (Anzai et al., 1997) with a DNA sequencer (ABI Prism 3730; Applied Biosystems). An almost-complete $16 \mathrm{~S}$ rRNA gene sequence (1443 nt) of strain $\mathrm{ABP}-4^{\mathrm{T}}$ was compared against $16 \mathrm{~S}$ rRNA gene sequences available from the EzTaxon server (Chun et al., 2007), the Ribosomal Database Project (Maidak et al., 2001) and GenBank database (http://blast.ncbi.nlm.nih.gov/Blast. cgi). Analysis of the sequence data was performed by using the software package BioEdit (Hall, 1999) and MEGA, version 3.1 (Kumar et al., 2004), after multiple alignments of the data by CLUSTAL_X (Thompson et al., 1997). Distances (corrected according to Kimura's two-parameter model; Kimura, 1983) were calculated and clustering was performed with the neighbour-joining method (Saitou \& Nei, 1987). The maximum-likelihood (Felsenstein, 1981) and maximum-parsimony (Kluge \& Farris, 1969) trees were generated by using the treeing algorithms contained in the PHYLIP software package (Felsenstein, 1993). In each case, bootstrap values were calculated based on 1000 replications.

Phylogenetic analyses based on 16S rRNA gene sequence revealed that strain $\mathrm{ABP}-4^{\mathrm{T}}$ was closely related to the species of the genera Roseateles (95.9-96.5\% sequence similarity), Aquabacterium (94.7-96.4\%), Kinneretia (96.2\%), Aquincola (96.1\%) and Pelomonas (95.0-96.0\%). Strain ABP-4 ${ }^{\mathrm{T}}$ formed a deep phyletic cluster with A. fontiphilum CS $-6^{\mathrm{T}}$, A. commune $\mathrm{B} 8^{\mathrm{T}}$, A. citratiphilum $\mathrm{B} 4^{\mathrm{T}}$ and A. parvum $\mathrm{B}^{\mathrm{T}}$ within the order Burkholderiales in the neighbour-joining tree (Fig. 1). The overall topologies of the phylogenetic trees obtained with the maximum-likelihood and maximumparsimony methods were similar. Sequence similarity calculations (over $1400 \mathrm{bp}$ ) indicated that strain $\mathrm{ABP}-4^{\mathrm{T}}$ was closely related to $A$. fontiphilum CS- $6^{\mathrm{T}}(96.4 \%$ 16S rRNA gene sequence similarity), A. commune $\mathrm{B} 88^{\mathrm{T}}(96.1 \%)$, A. citratiphilum $\mathrm{B}^{\mathrm{T}}(95.5 \%)$ and $A$. parvum $\mathrm{B}^{\mathrm{T}}(94.7 \%)$. In addition, $16 \mathrm{~S}$ rRNA gene sequence similarity calculations indicated that 


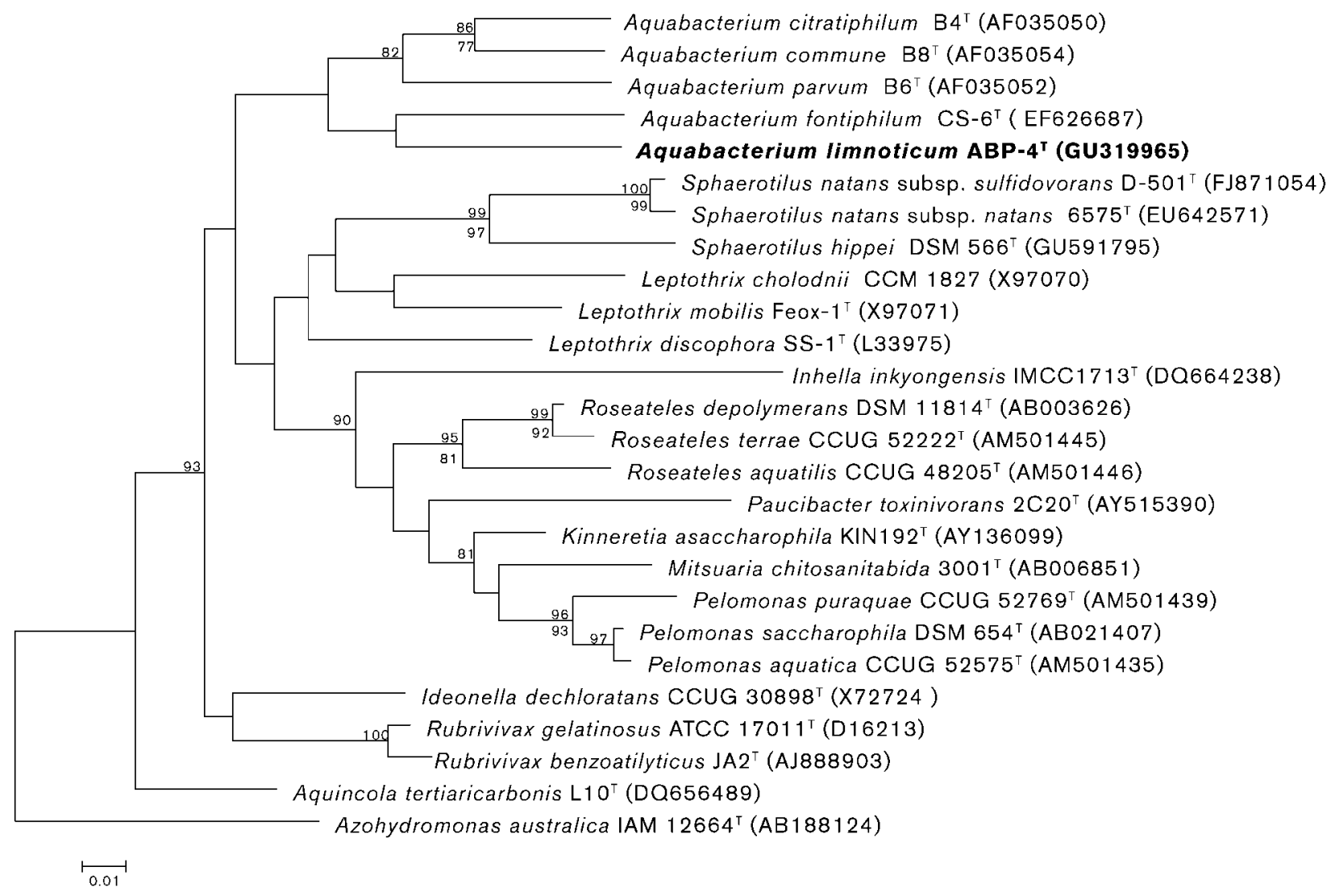

Fig. 1. Neighbour-joining phylogenetic tree based on 16S rRNA gene sequences showing the position of $A$. limnoticum ABP$4^{\top}$ and related taxa in the order Burkholderiales of the class Betaproteobacteria. Numbers at nodes are bootstrap percentages $>70 \%$ based on the neighbour-joining (above nodes) and maximum-parsimony (below nodes) tree-making algorithms. Azohydromonas australica IAM $12664^{\top}$ was used as an out-group. Bar, 0.01 substitutions per nucleotide position.

strain $\mathrm{ABP}-4^{\mathrm{T}}$ is closely related to Roseateles terrae CCUG $52222^{\mathrm{T}}$ and Roseateles aquatilis CCUG $48205^{\mathrm{T}}$ (96.5\% $16 \mathrm{~S}$ rRNA gene sequence similarity), Kinneretia asaccharophila KIN192 ${ }^{\mathrm{T}}$ (96.2\% $16 \mathrm{~S}$ rRNA gene sequence similarity) and Aquincola tertiaricarbonis $\mathrm{L}_{10}{ }^{\mathrm{T}}$ (96.1\% $16 \mathrm{~S} \mathrm{rRNA}$ gene sequence similarity). However, these four related strains exhibit distinctly deeper branches in the phylogenetic tree (Fig. 1).

DNA-DNA hybridization experiments were carried out by using the method of Ezaki et al. (1989). The level of DNADNA relatedness of strain ABP- $4^{\mathrm{T}}$ with $A$. fontiphilum CS $-6^{\mathrm{T}}$, A. commune $\mathrm{B} 8^{\mathrm{T}}$, A. citratiphilum $\mathrm{B} 4^{\mathrm{T}}$ and $A$. parvum $\mathrm{B}^{\mathrm{T}}$ was $31.0 \pm 1.2 \%, 15.8 \pm 1.3 \%, 16.5 \pm 1.3 \%$ and $36.8 \pm 1.2 \%$, respectively. Since the recommended DNA-DNA relatedness threshold for the definition of a species is $70 \%$ (Wayne et al., 1987), these results indicate that strain $\mathrm{ABP}-4^{\mathrm{T}}$ does not belong to any known species of the genus Aquabacterium.

The fatty acid profiles of strain $\mathrm{ABP}-4^{\mathrm{T}}$, A. fontiphilum CS- $6^{\mathrm{T}}$, A. commune $\mathrm{B} 8^{\mathrm{T}}$, A. citratiphilum $\mathrm{B} 4^{\mathrm{T}}$ and A. parvum $B 6^{\mathrm{T}}$ were determined using cells grown on $\mathrm{R} 2 \mathrm{~A}$ agar at $30{ }^{\circ} \mathrm{C}$ for 2 days. The fatty acid methyl esters were prepared, separated and identified by using the Instant FAME method of the Microbial Identification System (MIDI) version 6.0B and the RTSBA6 6.00 database. All five strains had straightchain fatty acids, unsaturated fatty acids and hydroxyl fatty acids. The fatty acid profile of strain $\mathrm{ABP}-4^{\mathrm{T}}$ was similar to those of the other four Aquabacterium species, although there were differences in the proportions of some components (Table 1$)$. The major fatty acids $(>10.0 \%)$ of strain $\mathrm{ABP}-4^{\mathrm{T}}$ were summed feature 3 (comprising $\mathrm{C}_{16: 1} \omega 7 \mathrm{c}$ and/ or $\left.\mathrm{C}_{16: 1} \omega 6 c, 33.8 \%\right), \mathrm{C}_{18: 1} \omega 7 c(19.2 \%)$ and $\mathrm{C}_{16: 0}$ $(18.3 \%)$. The major cellular hydroxy fatty acid in strain $\mathrm{ABP}-4^{\mathrm{T}}$ was $\mathrm{C}_{10: 0} 3-\mathrm{OH}(2.4 \%)$. Isoprenoid quinones were extracted and purified according to the method of Collins (1985) and were analysed by HPLC. The respiratory quinones of strain $\mathrm{ABP}-4^{\mathrm{T}}$ were Q-8 $(81.3 \%)$ and Q-7 $(18.7 \%)$. The respiratory quinones of $A$. commune $\mathrm{B} 8^{\mathrm{T}}$ were Q-8 (76.2\%) and Q-7 (23.8\%). The DNA G + C content of strain ABP- $4^{\mathrm{T}}$, determined by HPLC according to Mesbah et al. (1989), was $68.6 \pm 1.0 \mathrm{~mol} \%$.

Polar lipids were extracted and analysed by 2D TLC according to Embley \& Wait (1994). Strain ABP-4 ${ }^{\mathrm{T}}$ exhibited 


\section{Table 1. Cellular fatty acid composition of Aquabacterium species}

All data are from this study. All strains were grown on R2A agar at $30{ }^{\circ} \mathrm{C}$ for 2 days. Values are percentages of the total fatty acids; fatty acids that make up $<1 \%$ of the total are not shown or indicated by -. For unsaturated fatty acids, the position of the double bond is located by counting from the methyl $(\omega)$ end of the carbon chain. cis isomer is indicated by the suffix $c$.

\begin{tabular}{|c|c|c|c|c|c|}
\hline Fatty acid & A. limnoticum $\mathrm{ABP}-4^{\mathrm{T}}$ & A. fontiphilum CS-6 ${ }^{\mathrm{T}}$ & A. commune $\mathrm{B8}^{\mathrm{T}}$ & A. citratiphilum $\mathrm{B}^{\mathrm{T}}$ & A. parvum $\mathrm{B}^{\mathrm{T}}$ \\
\hline $\mathrm{C}_{12: 0}$ & 4.9 & 7.8 & 5.6 & 3.4 & 3.3 \\
\hline$C_{16: 0}$ & 18.3 & 20.6 & 31.0 & 19.0 & 21.3 \\
\hline $\mathrm{C}_{18: 0}$ & 7.5 & 1.7 & 1.6 & 2.0 & 7.8 \\
\hline $\mathrm{C}_{10: 0} 3-\mathrm{OH}$ & 2.4 & 6.6 & 5.8 & 7.8 & 6.8 \\
\hline $\mathrm{C}_{18: 1} \omega 7 c$ & 19.2 & 38.6 & 8.8 & 20.1 & 18.2 \\
\hline $\mathrm{C}_{18: 1} \omega 9 c$ & - & 1.8 & - & 1.2 & 1.4 \\
\hline Summed feature $3^{\star}$ & 33.8 & 18.5 & 42.4 & 35.0 & 30.4 \\
\hline
\end{tabular}

${ }^{*}$ Summed features are groups of two or three fatty acids that cannot be separated by GLC using the MIDI system. Summed feature 3 comprises $\mathrm{C}_{16: 1} \omega 7 c$ and/or $\mathrm{C}_{16: 1} \omega 6 c$.

a complex polar lipid profile consisting of phosphatidylethanolamine (PE), phosphatidylglycerol (PG), phosphatidylserine (PS), diphosphatidylglycerol (DPG) and four uncharacterized phospholipids (PL1-PL4) (see Supplementary Fig. S1, available in IJSEM Online). Like its closest relatives $A$. fontiphilum $\mathrm{CS}-6^{\mathrm{T}}, A$. commune $\mathrm{B} 8^{\mathrm{T}}, A$. citratiphilum $\mathrm{B} 4^{\mathrm{T}}$ and $A$. parvum $\mathrm{B} 6^{\mathrm{T}}$, strain $\mathrm{ABP}-4^{\mathrm{T}}$ exhibited a very similar polar lipid profile, and they all had PE, PG, PS, DPG and PL3. However, PL1 was absent in A. parvum $\mathrm{B}^{\mathrm{T}}$, but present in strain $\mathrm{ABP}-4^{\mathrm{T}}$, A. fontiphilum $\mathrm{CS}-6^{\mathrm{T}}, A$. commune $\mathrm{B} 8^{\mathrm{T}}$ and A. citratiphilum $\mathrm{B} 4^{\mathrm{T}}$. PL2 was detected in strain $\mathrm{ABP}-4^{\mathrm{T}}, A$. commune $\mathrm{B} 8^{\mathrm{T}}$ and $A$. parvum $\mathrm{B}^{\mathrm{T}}$ but not detected in $A$. fontiphilum $\mathrm{CS}-6^{\mathrm{T}}$ and $A$. citratiphilum $\mathrm{B} 4^{\mathrm{T}}$. PL4 was present in strain $\mathrm{ABP}-4^{\mathrm{T}}, A$. citratiphilum $\mathrm{B} 4^{\mathrm{T}}$ and $A$. parvum $\mathrm{B} 6^{\mathrm{T}}$ but absent in A. fontiphilum $\mathrm{CS}-6^{\mathrm{T}}$ and $A$. commune $\mathrm{B} 8^{\mathrm{T}}$. In addition, PL5 was detected in A. commune $\mathrm{B}^{\mathrm{T}}$ and $A$. parvum $\mathrm{B} 6^{\mathrm{T}}$. These results suggested that there are some differences in the polar lipid profiles among them, although they belong to the same genus and have very similar profiles.

The physiological, biochemical and morphological characteristics of strain $\mathrm{ABP}-4^{\mathrm{T}}$ are given in the species description, Table 2 and Supplementary Table S1 (available in IJSEM Online). Phenotypic examination revealed many common traits between the novel strain and its closest relatives, A. fontiphilum $\mathrm{CS}-6^{\mathrm{T}}, A$. commune $\mathrm{B} 8^{\mathrm{T}}, A$. citratiphilum $\mathrm{B} 4^{\mathrm{T}}$ and $A$. parvum $\mathrm{B}^{\mathrm{T}}$. However, strain ABP $-4^{\mathrm{T}}$ could be clearly differentiated from these four species by the absence of motility, by the utilization of chlorate as electron acceptor but not nitrate, by the inability to hydrolyse aesculin, by the absence of C8 esterase lipase activity and by the presence of $\alpha$-glucosidase activity (Table 2 ), and by its ability to utilize glycogen, p-hydroxyphenylacetic acid, $\alpha$-keto butyric acid, $\alpha$-keto glutaric acid and Lasparagine as sole carbon sources (Supplementary Table S1).
Strain $\mathrm{ABP}-4^{\mathrm{T}}$ is Gram-negative, rod-shaped, facultatively anaerobic and oxidase-positive. Growth is chemo-heterotrophic and occurs under mesophilic and neutrophilic conditions. Predominant fatty acids contain summed feature 3 (comprising $\mathrm{C}_{16: 1} \omega 7 c$ and/or $\mathrm{C}_{16: 1} \omega 6 c$ ), $\mathrm{C}_{18: 1}$ $\omega 7 c$ and $\mathrm{C}_{16: 0}$. The DNA $\mathrm{G}+\mathrm{C}$ content is $68.6 \mathrm{~mol} \%$. These characteristics of strain $\mathrm{ABP}-4^{\mathrm{T}}$ are consistent with the description of the genus Aquabacterium (Kalmbach et al., 1999; Lin et al., 2009).

In addition, the data obtained from $16 \mathrm{~S}$ rRNA gene sequence comparisons showed that the novel strain has a close phylogenetic relationship $(>96.0 \%$ sequence similarity) to the genera Roseateles, Kinneretia and Aquincola. However, the novel strain could be clearly differentiated from Roseateles species (Suyama et al., 1999; Gomila et al., 2008) by the absence of bacteriochlorophyll $a$ production, by the utilization of nitrate or chlorate as an alternative electron acceptor, by the facultatively anaerobic growth, and by the high levels of $\mathrm{C}_{12: 0}$ and the absence of $\mathrm{C}_{15: 0}$. The properties such as the presence of catalase activity, and the absence of $\mathrm{C}_{8: 0} 3-\mathrm{OH}$ and the presence of $\mathrm{C}_{10: 0} 3-\mathrm{OH}$, allow good discrimination of the novel strain from the species of the genus Kinneretia (Gomila et al., 2010). Some features of the novel strain, such as the ability to utilize chlorate as an alternative electron acceptor, the high levels of $\mathrm{C}_{18: 1} \omega 7 c$ and the absence of $\mathrm{C}_{15: 1}, \mathrm{C}_{17: 0}$ and $\mathrm{C}_{17: 0}$ cyclo, help to separate the novel strain from Aquincola species (Lechner et al., 2007). These results suggest that strain $\mathrm{ABP}-4^{\mathrm{T}}$ belongs to a genus which is evenly distant from the genera Roseateles, Kinneretia and Aquincola.

On the basis of the data obtained from 16S rRNA gene sequence comparisons, strain $\mathrm{ABP}-4^{\mathrm{T}}$ occupies a distinct position within the genus Aquabacterium. The phylogenetic insight is supported by the unique combination of chemotaxonomic and biochemical characteristics of the novel strain. 
Table 2. Differential characteristics of Aquabacterium species

All data are from this study except the $\mathrm{G}+\mathrm{C}$ content of A. fontiphilum CS-6 ${ }^{\mathrm{T}}$ (Lin et al., 2009) and A. commune $\mathrm{B} 8^{\mathrm{T}}$, A. citratiphilum $\mathrm{B}^{\mathrm{T}}$ and A. parvum $\mathrm{B} 6^{\mathrm{T}}$ (Kalmbach et al., 1999). +, Positive reaction; -, negative reaction. All strains are Gram-negative, mesophilic, neutrophilic, non-spore-forming, and positive for oxidase, catalase and leucine arylamidase activities. All strains are negative for DNase, trypsin, $\alpha$-galactosidase, $\beta$-galactosidase, $\beta$-glucuronidase, $\beta$-glucosidase, $N$-acetyl- $\beta$-glucosaminidase, $\alpha$-mannosidase and $\alpha$-fucosidase activities, hydrolysis of starch, indole production and glucose acidification.

\begin{tabular}{|c|c|c|c|c|c|}
\hline Characteristic & A. limnoticum $\mathrm{ABP}-4^{\mathrm{T}}$ & A. fontiphilum CS-6 ${ }^{\mathrm{T}}$ & A. commune $\mathrm{B8}^{\mathrm{T}}$ & A. citratiphilum $\mathrm{B} 4^{\mathrm{T}}$ & A. parvum $\mathrm{B}^{\mathrm{T}}$ \\
\hline Motility & - & + & + & + & + \\
\hline \multicolumn{6}{|l|}{ Reduction of: } \\
\hline $\mathrm{NO}_{3}^{-}$ & - & + & + & + & + \\
\hline $\mathrm{ClO}_{3}^{-}$ & + & - & - & - & - \\
\hline \multicolumn{6}{|l|}{ Hydrolysis of: } \\
\hline Urea & - & + & - & + & + \\
\hline Casein & - & - & + & - & - \\
\hline Gelatin & - & + & - & + & - \\
\hline Aesculin & - & + & + & + & + \\
\hline \multicolumn{6}{|l|}{ Enzymic activities: } \\
\hline Arginine dihydrolase & - & - & + & + & - \\
\hline Alkaline phosphatase & + & + & + & + & - \\
\hline C8 esterase lipase & - & + & + & + & + \\
\hline C14 lipase & - & + & - & + & - \\
\hline Valine arylamidase & - & + & - & - & - \\
\hline Cystine arylamidase & - & + & + & - & - \\
\hline$\alpha$-Chymotrypsin & - & - & - & + & - \\
\hline Acid phosphatase & - & - & - & + & - \\
\hline $\begin{array}{l}\text { Naphthol-AS-BI- } \\
\text { phosphohydrolase }\end{array}$ & + & + & - & - & + \\
\hline$\alpha$-Glucosidase & + & - & - & - & - \\
\hline \multicolumn{6}{|l|}{ Assimilation of: } \\
\hline Glucose & - & + & - & + & - \\
\hline Arabinose & - & + & - & + & - \\
\hline Mannose & - & + & - & - & - \\
\hline Mannitol & - & + & - & + & - \\
\hline$N$-Acetylglucosamine & - & + & - & + & - \\
\hline Maltose & - & + & - & + & - \\
\hline Gluconate & - & + & - & + & - \\
\hline Caprate & - & - & - & + & - \\
\hline Adipate & + & + & - & - & - \\
\hline Malate & + & + & - & + & + \\
\hline Citrate & - & + & - & - & - \\
\hline Phenyl-acetate & - & + & - & - & - \\
\hline DNA G $+\mathrm{C}$ content $(\mathrm{mol} \%)$ & 68.6 & 63.4 & 66 & 66 & 65 \\
\hline
\end{tabular}

It is clear from the phylogenetic and phenotypic data that the strain $\mathrm{ABP}-4^{\mathrm{T}}$ constitutes a novel member of the genus Aquabacterium. However, strain $\mathrm{ABP}-4^{\mathrm{T}}$ could be differentiated from A. fontiphilum CS-6 ${ }^{\mathrm{T}}$, A. commune $\mathrm{B} 8^{\mathrm{T}}$, A. citratiphilum $\mathrm{B} 4^{\mathrm{T}}$ and $A$. parvum $\mathrm{B}^{\mathrm{T}}$ by a combination of physiological and biochemical characteristics (Table 2 and Supplementary Table S1). Hence, strain ABP-4 ${ }^{\mathrm{T}}$ constitutes a novel member of the genus Aquabacterium. The name Aquabacterium limnoticum sp. nov. is proposed for this taxon.

In this study, the two characteristics of absence of motility and the utilization of chlorate as electron acceptor were not observed for Aquabacterium species as they were in previous publications (Kalmbach et al., 1999; Lin et al., 2009). Differences were also noted in the catalase production of Aquabacterium species from the earlier reported data (Kalmbach et al., 1999). Additionally, the chemotaxonomic characteristics of Aquabacterium species such as the major fatty acids containing summed feature 3 (comprising $\mathrm{C}_{16: 1} \omega 7 c$ and/or $\mathrm{C}_{16: 1} \omega 6 c$ ), $\mathrm{C}_{18: 1} \omega 7 c$ and $\mathrm{C}_{16: 0}$, and the presence of hydroxy fatty acid $\mathrm{C} 10: 03-\mathrm{OH}$ may be helpful for distinguishing Aquabacterium from the other genera in the class Betaproteobacteria.

\section{Emended description of the genus Aquabacterium Kalmbach et al. 1999}

The formal description given by Kalmbach et al. (1999) remains correct except that some species are non-motile, catalase-positive, and use nitrate or chlorate as an alternative 
electron acceptor. The major cellular fatty acids are summed feature 3 (comprising $\mathrm{C}_{16: 1} \omega 7 c$ and/or $\mathrm{C}_{16: 1}$ $\omega 6 c), \mathrm{C}_{18: 1} \omega 7 c$ and $\mathrm{C}_{16: 0}$, and the major hydroxy fatty acid is $\mathrm{C}_{10: 0} 3-\mathrm{OH}$ except that some species also contain $\mathrm{C}_{12: 0} 2-\mathrm{OH}$.

\section{Description of Aquabacterium limnoticum sp. nov.}

Aquabacterium limnoticum (lim.no'ti.cum. Gr. n. limnê, pool of standing water, lake; L. neut. suff. -ticum, suff. denoting made of or belonging to; N. L. neut. adj. limnoticum, from or belonging to a lake).

Cells are Gram-negative, facultatively anaerobic, nonspore-forming, non-motile, short-rod-shaped and chemoheterotrophic. Poly- $\beta$-hydroxybutyrate accumulation is not observed. After $48 \mathrm{~h}$ of incubation on R2A agar at $30{ }^{\circ} \mathrm{C}$, the mean cell size is approximately $0.8-1.0 \mu \mathrm{m}$ in diameter and $1.3-2.0 \mu \mathrm{m}$ in length. Colonies are semitransparent, convex, round and smooth with entire edges. The colony size is approximately $1.0-1.7 \mathrm{~mm}$ in diameter on R2A agar after $72 \mathrm{~h}$ incubation at $25{ }^{\circ} \mathrm{C}$. Growth occurs at $20-40{ }^{\circ} \mathrm{C}$ (optimum, $30-37{ }^{\circ} \mathrm{C}$ ), at $\mathrm{pH} 7.0-10.0$ (optimum, pH 7.0-9.0) and with $0-3 \% \mathrm{NaCl}$ (optimum, $0 \%)$. Positive for oxidase activity and weakly positive for catalase activity. Positive for hydrolysis of corn oil. Negative for hydrolysis of urea, starch, gelatin, casein, Tweens 20, 40, 60 and 80. Chlorate serves as an alternative electron acceptor, but nitrate, nitrite, sulfate or iron (III) do not. In API 20NE tests, positive reactions for assimilation of adipate and malate, and negative reactions for nitrate reduction, indole production, glucose acidification, aesculin and gelatin hydrolysis, arginine dihydrolase, urease and $\beta$-galactosidase activities and assimilation of glucose, arabinose, mannose, mannitol, $\mathrm{N}$-acetylglucosamine, maltose, gluconate, caprate, citrate and phenylacetate. In the API ZYM kit, alkaline phosphatase, leucine arylamidase, naphthol-AS-BI-phosphohydrolase and $\alpha$ glucosidase activities are present and C4 esterase, C8 esterase lipase, C14 lipase, valine arylamidase, cysteine arylamidase, trypsin, $\alpha$-chymotrypsin, acid phosphatase, $\alpha$-galactosidase, $\beta$-galactosidase, $\beta$-glucuronidase, $\beta$-glucosidase, $N$-acetyl- $\beta$-glucosaminidase, $\alpha$-mannosidase and $\alpha$ fucosidase activities are absent. The following compounds are utilized as sole carbon sources in the GN2 microplate: glycogen, Tween 80 , pyruvic acid methyl ester, $\beta$-hydroxybutyric acid, p-hydroxyphenylacetic acid, $\alpha$-keto butyric acid, $\alpha$-keto glutaric acid, DL-lactic acid, succinic acid, bromosuccinic acid, succinamic acid, L-alanine, L-asparagine and L-glutamic acid. All other substrates in the GN2 microplate are not utilized. Resistant to rifampicin and sensitive to penicillin G, ampicillin, chloramphenicol, gentamicin, kanamycin, tetracycline, novobiocin, streptomycin, sulfamethoxazole plus trimethoprim and nalidixic acid. The major fatty acids are summed feature 3 (comprising $\mathrm{C}_{16: 1} \omega 7 c$ and/or $\left.\mathrm{C}_{16: 1} \omega 6 c\right), \mathrm{C}_{18: 1} \quad \omega 7 c$ and $\mathrm{C}_{16: 0}$. The major hydroxy fatty acid is $\mathrm{C} 10: 03-\mathrm{OH}$.
The predominant polar lipids were phosphatidylethanolamine, phosphatidylglycerol, phosphatidylserine, diphosphatidylglycerol and four uncharacterized phospholipids. The DNA G + C content is $68.6 \mathrm{~mol} \%$. The major respiratory quinone is Q-8.

The type strain is ABP $-4^{\mathrm{T}}\left(=\mathrm{BCRC} 80167^{\mathrm{T}}=\mathrm{KCTC} 23306^{\mathrm{T}}\right)$ isolated from a freshwater spring, Taichung County, Taiwan.

\section{References}

Anzai, Y., Kudo, Y. \& Oyaizu, H. (1997). The phylogeny of the genera Chryseomonas, Flavimonas, and Pseudomonas supports synonymy of these three genera. Int J Syst Bacteriol 47, 249-251.

Breznak, J. A. \& Costilow, R. N. (1994). Physicochemical factors in growth. In Methods for General and Molecular Bacteriology, pp. 137154. Edited by P. Gerhardt, R. G. E. Murray, W. A. Wood \& N. R. Krieg. Washington, DC: American Society for Microbiology.

Chen, W. M., Laevens, S., Lee, T. M., Coenye, T., De Vos, P., Mergeay, M. \& Vandamme, P. (2001). Ralstonia taiwanensis sp. nov., isolated from root nodules of Mimosa species and sputum of a cystic fibrosis patient. Int J Syst Evol Microbiol 51, 1729-1735.

Chun, J., Lee, J.-H., Jung, Y., Kim, M., Kim, S., Kim, B. K. \& Lim, Y. W. (2007). EzTaxon: a web-based tool for the identification of prokaryotes based on 16S ribosomal RNA gene sequences. Int J Syst Evol Microbiol 57, 2259-2261.

Collins, M. D. (1985). Isoprenoid quinone analysis in classification and identification. In Chemical Methods in Bacterial Systematics, pp. 267-287. Edited by M. Goodfellow \& D. E. Minnikin. London: Academic Press.

Embley, T. M. \& Wait, R. (1994). Structural lipids of eubacteria. In Chemical Methods in Prokaryotic Systematics, pp. 121-161. Edited by M. Goodfellow \& A. G. O’Donnell. England: John Wiley \& Sons Ltd.

Ezaki, T., Hashimoto, Y. \& Yabuuchi, E. (1989). Fluorometric deoxyribonucleic acid-deoxyribonucleic acid hybridization in microdilution wells as an alternative to membrane filter hybridization in which radioisotopes are used to determine genetic relatedness among bacterial strains. Int J Syst Bacteriol 39, 224-229.

Felsenstein, J. (1981). Evolutionary trees from DNA sequences: a maximum likelihood approach. J Mol Evol 17, 368-376.

Felsenstein, J. (1993). PHYLIP (phylogeny inference package), version 3.5c. Distributed by the author. Department of Genome Sciences, University of Washington, Seattle, USA.

Gomila, M., Bowien, B., Falsen, E., Moore, E. R. B. \& Lalucat, J. (2008). Description of Roseateles aquatilis sp. nov. and Roseateles terrae sp. nov., in the class Betaproteobacteria, and emended description of the genus Roseateles. Int J Syst Evol Microbiol 58, 6-11.

Gomila, M., Pinhassi, J., Falsen, E., Moore, E. R. B. \& Lalucat, J. (2010). Kinneretia asaccharophila gen. nov., sp. nov., isolated from a freshwater lake, a member of the Rubrivivax branch of the family Comamonadaceae. Int J Syst Evol Microbiol 60, 809-814.

Hall, T. A. (1999). BioEdit: a user-friendly biological sequence alignment editor and analysis program for Windows 95/98/NT. Nucleic Acids Symp Ser 41, 95-98.

Kalmbach, S., Manz, W., Wecke, J. \& Szewzyk, U. (1999). Aquabacterium gen. nov., with description of Aquabacterium citratiphilum sp. nov., Aquabacterium parvum sp. nov. and Aquabacterium commune sp. nov., three in situ dominant bacterial species from the Berlin drinking water system. Int J Syst Bacteriol 49, 769-777.

Kimura, M. (1983). The Neutral Theory of Molecular Evolution. Cambridge: Cambridge University Press. 
Kluge, A. G. \& Farris, F. S. (1969). Quantitative phyletics and the evolution of anurans. Syst Zool 18, 1-32.

Kumar, S., Tamura, K. \& Nei, M. (2004). MEGA3: integrated software for Molecular Evolutionary Genetics Analysis and sequence alignment. Brief Bioinform 5, 150-163.

Lechner, U., Brodkorb, D., Geyer, R., Hause, G., Härtig, C., Auling, G., Fayolle-Guichard, F., Piveteau, P., Müller, R. H. \& Rohwerder, T. (2007). Aquincola tertiaricarbonis gen. nov., sp. nov., a tertiary butyl moiety-degrading bacterium. Int J Syst Evol Microbiol 57, 12951303.

Lin, M. C., Jiang, S. R., Chou, J. H., Arun, A. B., Young, C. C. \& Chen, W. M. (2009). Aquabacterium fontiphilum sp. nov., isolated from spring water. Int J Syst Evol Microbiol 59, 681-685.

Maidak, B. L., Cole, J. R., Lilburn, T. G., Parker, C. T., Jr, Saxman, P. R., Farris, R. J., Garrity, G. M., Olsen, G. J., Schmidt, T. M. \& Tiedje, J. M. (2001). The RDP-II (Ribosomal Database Project). Nucleic Acids Res 29, 173-174.

Mesbah, M., Premachandran, U. \& Whitman, W. B. (1989). Precise measurement of the GC content of deoxyribonucleic acid by highperformance liquid chromatography. Int J Syst Bacteriol 39, 159-167.

Nokhal, T. H. \& Schlegel, H. G. (1983). Taxonomic study of Paracoccus denitrijicans. Int J Syst Bacteriol 33, 26-37.
Powers, E. M. (1995). Efficacy of the Ryu nonstaining KOH technique for rapidly determining gram reactions of food-borne and waterborne bacteria and yeasts. Appl Environ Microbiol 61, 3756-3758.

Saitou, N. \& Nei, M. (1987). The neighbor-joining method: a new method for reconstructing phylogenetic trees. Mol Biol Evol 4, 406-425.

Smibert, R. M. \& Krieg, N. R. (1994). Phenotypic characterization. In Methods for General and Molecular Bacteriology, pp. 607-654. Edited by P. Gerhardt, R. G. E. Murray, W. A. Wood \& N. R. Krieg. Washington, DC: American Society for Microbiology.

Suyama, T., Shigematsu, T., Takaichi, S., Nodasaka, Y., Fujikawa, S., Hosoya, H., Tokiwa, Y., Kanagawa, T. \& Hanada, S. (1999). Roseateles depolymerans gen. nov., sp. nov., a new bacteriochlorophyll $a$ containing obligate aerobe belonging to the $\beta$-subclass of the Proteobacteria. Int J Syst Bacteriol 49, 449-457.

Thompson, J. D., Gibson, T. J., Plewniak, F., Jeanmougin, F. \& Higgins, D. G. (1997). The CLUSTAL_X windows interface: flexible strategies for multiple sequence alignment aided by quality analysis tools. Nucleic Acids Res 25, 4876-4882.

Wayne, L. G., Brenner, D. J., Colwell, R. R., Grimont, P. A. D., Kandler, O., Krichevsky, M. I., Moore, L. H., Moore, W. E. C., Murray, R. G. E. \& other authors (1987). Report of the ad hoc committee on reconciliation of approaches of bacterial systematics. Int J Syst Bacteriol 37, 463-464. 